Hadžić Neven

Kozmar Hrvoje

Tomić Marko

http://dx.doi.org/10.21278/brod69201

ISSN 0007-215X

eISSN 1845-5859

\title{
FEASIBILITY OF INVESTMENT IN RENEWABLE ENERGY SYSTEMS FOR SHIPYARDS
}

UDC 629.5.081: 629.5.082

Professional paper

\begin{abstract}
Summary
Shipbuilding industry is generally considered as one of the key global industries. It consumes a significant amount of energy and leaves a strong footprint on the environment. It is therefore required to try to increase renewable energy sources in the shipbuilding industry in accordance with the adopted international legislation. This will improve energy efficiency of shipyards and reduce their impact on the environment. The present preliminary study contributes to those goals as application of sustainable renewable energy systems in ship production industry is considered. The analysis is performed for solar panels, tidal and wind turbines with respect to their technology readiness and investment costs, as well as for the total energy consumption. While in the present work the research hypothesis is studied on example of a typical Croatian shipyard, the general findings are expected to be widely applicable to all shipyards. The solar panels are considered as the most suitable renewable technology, while the investment return period for introducing solar panels to satisfy the entire electrical energy demand in this particular case is approximately seven years. The impact of introducing this green shipbuilding approach is considered beneficial in comparison with current conventional electrical energy production based on conventional energy sources.
\end{abstract}

Key words: $\quad$ Shipyard design; Renewable energy; Solar energy; Green industry; Case study

\section{Introduction}

Shipbuilding is globally considered as one of the key industries. It focuses on a production of technologically very demanding and complex products that requires large energy consumption and makes considerable footprint on the environment. New measures related to reduction of carbon dioxide footprint are successfully adopted in Maritime Pollution (MARPOL) amendments based on Energy Efficiency Design Index (EEDI), [1]. This enables estimation of carbon dioxide emission for a specific ship with characteristic design parameters, [2]. The goal is to achieve energy efficient and less polluting equipment and engines, e.g. [3], which consequently leads to an improved ship design with respect to the environment. However, application of renewable energy sources and energy efficient concepts to enhance carbon dioxide reduction is quite rare in ship production industry. It is 
therefore required to analyze this possibility on example of a typical shipyard, whereas the performed analysis yields an approach that is to be applicable in the global ship production industry.

The application of renewable energy sources in ship production industry is in line with United Nations (UN) policies for environment-friendly industry and greener industrial footprint initiative [4]. The main pathway towards sustainable industrial development is by rationally exploiting material and energy resources. An accomplishment of such a demanding and challenging task is quite complex, as it involves multiple stakeholder issues, e.g. industrial, financial and energy sector, local and state government, local community, investors, international agreements, which all need to be adequately addressed.

The UN initiative, [4], is based on four fundamental green industry parameters considering environmental friendly approach in material, waste, water and energy management. This approach is based on adopting obligatory legal framework, as well as on environment-related labeling of low-carbon products.

This initiative is particularly concerned with optimal energy consumption to reduce electricity generated from conventional energy sources, i.e. fossil fuels. With this respect, an application of renewable energy sources, such as solar, offshore and wind energy, e.g. [5], is strongly recommended, as it decreases production costs, creates new business opportunities, prevents an increase in energy price, ensures energy independent and diverse production systems, and enhances product competitiveness and enterprise ranking, [6].

This approach is in line with the European Union (EU) mandatory 20\% share in renewable energy sources in final energy consumption by the year of 2020, [7]. Given those facts the Croatian Government set three basic objectives, i.e. to develop secure, competitive and sustainable energy sector with emphasis on renewable energy sources, [8]. These recommendations are to be widely implemented in practice as to fully account for multiple benefits of this advanced approach for the energy and the environment. It is therefore the purpose of the present study to investigate a possibility of applying renewable energy sources in the shipbuilding industry.

A thorough literature survey reveals that the green shipbuilding concept has not been accordingly addressed in the global energy community so far. The studies that address complex interaction between general industry and energy management usually report on possible greenhouse gasses mitigation policies including continuous economic growth, environmental preservation, cost-benefit analysis of sustainable energy development as well as socioeconomic benefits and drawbacks, [9]. Various renewable energy scenarios were analyzed in [10] demonstrating health benefits as one of the most important socioeconomic indicators justifying the compliance costs associated with sustainable energy development. A concept of green industry should be considered in the context of the low-carbon society taking actions that are compatible with the principles of sustainable development, [11]. It is, therefore, necessary to demonstrate a high level of energy efficiency and application of the low-carbon production technologies, [12], as well as consumption and behavior patterns leading towards low levels of greenhouse gas emissions, [13].

A comparative policy scenario, exploring emission mitigation, renewable energy and energy efficiency in the United Kingdom and European Union (EU) industry using processoriented modelling approach is presented in [14]. It demonstrates critical importance of energy-efficient, cost-efficient and long-term decarbonisation of the industrial production. In line with that, an impact of two possible green-growth scenarios assuming conventional and large-scale renewable energy development on China GDP until 2050 is analyzed in [15] using dynamic computable general equilibrium model. An assessment of energy consumption and pollution emissions in case of an iron and steel industry is addressed in [16] resulting with 
performance indicators demonstrating inevitable necessity of rational and sustainable energy management for manufacturing industry. A similar study [17] reports an interaction between waste energy recovery an energy efficiency improvement in China's iron and steel industry.

An energy supply chain in the context of resource, technology, environment, infrastructure and socio-economic development interaction is considered for manufacturing sectors in China, [18], where critical energy sectors are identified using input-output analysis. A more detailed literature review and case study of energy management for a typical process industry company is analyzed in [19] emphasizing the importance of such an approach in the industrial sector. Along with that, current situation, regulatory changes and promotion of renewable energy sources in Spain are addressed in [20] while pointing out the necessary policy instrument leading towards achievement of future renewable energy goals. Some of these goals are analyzed in [21] using the system thinking approach with particular focus on energy supply, diversification, energy security and support schemes of Nordic countries.

The scope of the present study is to analyze a possibility of introducing renewable energy sources in a ship production industry. This is performed on an example of a typical shipyard, while the performed analysis yields an approach that is expected to be globally applicable in the ship production industry. This methodology is therefore expected to enhance decoupling of shipyards from conventional energy sources, and decreasing an environmental footprint of ship production industry. To achieve this goal, the annual electrical energy consumption in the typical shipyard is analyzed to determine its energy demand. An overview of renewable energy sources that can be considered for this implementation is outlined. An optimal solution is selected by considering the impact on the environment, society and shipyard business.

\section{Total electrical energy consumption for a typical shipyard}

The total annual energy consumption is analyzed for a typical shipyard (Uljanik, Croatia). Typical ship production process is reported in Fig. 1. It consists of several subprocesses, i.e. a) metal process, b) outfitting, c) surface treatment, d) material handling, e) quality control and f) ancillary services. During these processes, various operations are performed, i.e. flattening, cleaning, conserving, cutting, forming, welding, machining, assembling, dislocating, transporting, testing, air-conditioning, ventilating, lightening as well as the operations of a general consumption. These actions are performed to exploit and modify physical, chemical and mechanical properties of the used material, [22].

Almost all technology operations directly use electrical energy, while some of them, like flattening, conserving and thermal cutting rely on heat produced by mixture of oxygen $\left(\mathrm{O}_{2}\right)$ and acetylene $\left(\mathrm{C}_{2} \mathrm{H}_{2}\right)$ combustion. As relatively large amount of oxygen and acetylene is used during production process, shipyards are commonly equipped with separate facilities that produce those gases using electrical energy.

Along with shipyard core business, i.e. production process, the electrical energy is commonly consumed by ancillary services that enable operations like heating, airconditioning and ventilation (in each workshop, working place and office), lightening and general consumption.

Nevertheless, some estimates of the electrical energy consumption can be found in [23] where an approximate electrical energy consumption of $750 \mathrm{kWh}$ per ship lightweight ton is assessed with share of a) $18 \%$ for oxygen, b) $12 \%$ for carbon dioxide, c) $17 \%$ for acetylene, d) $19 \%$ for surface treatment, e) $21 \%$ for welding, and f) $13 \%$ for general consumption, Fig. 2. 


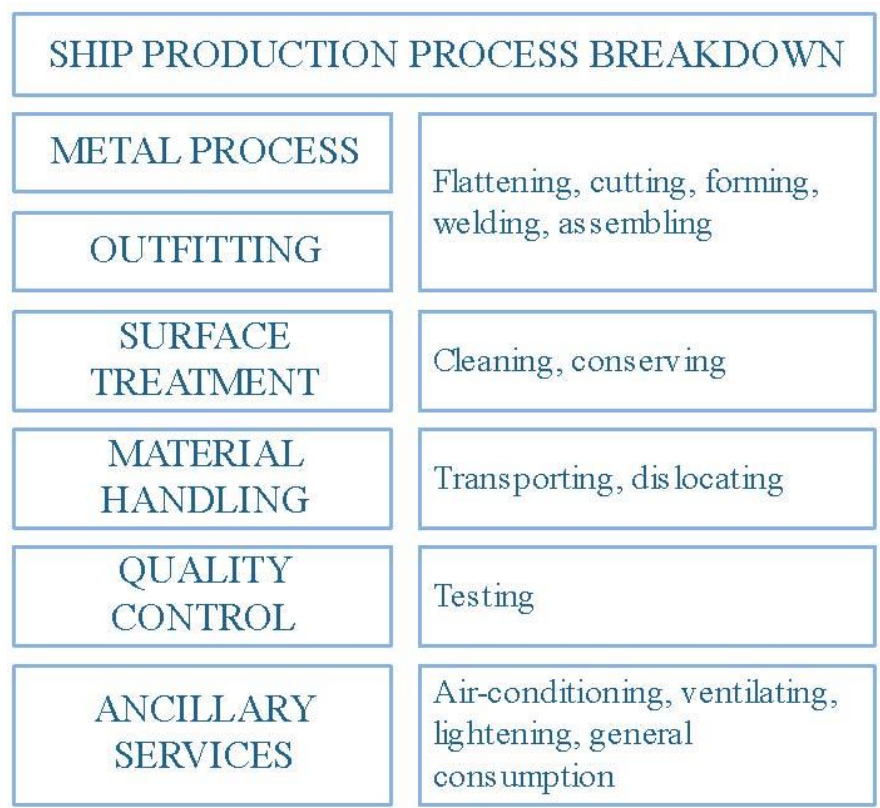

Fig. 1 Ship production process and operations that require electrical energy

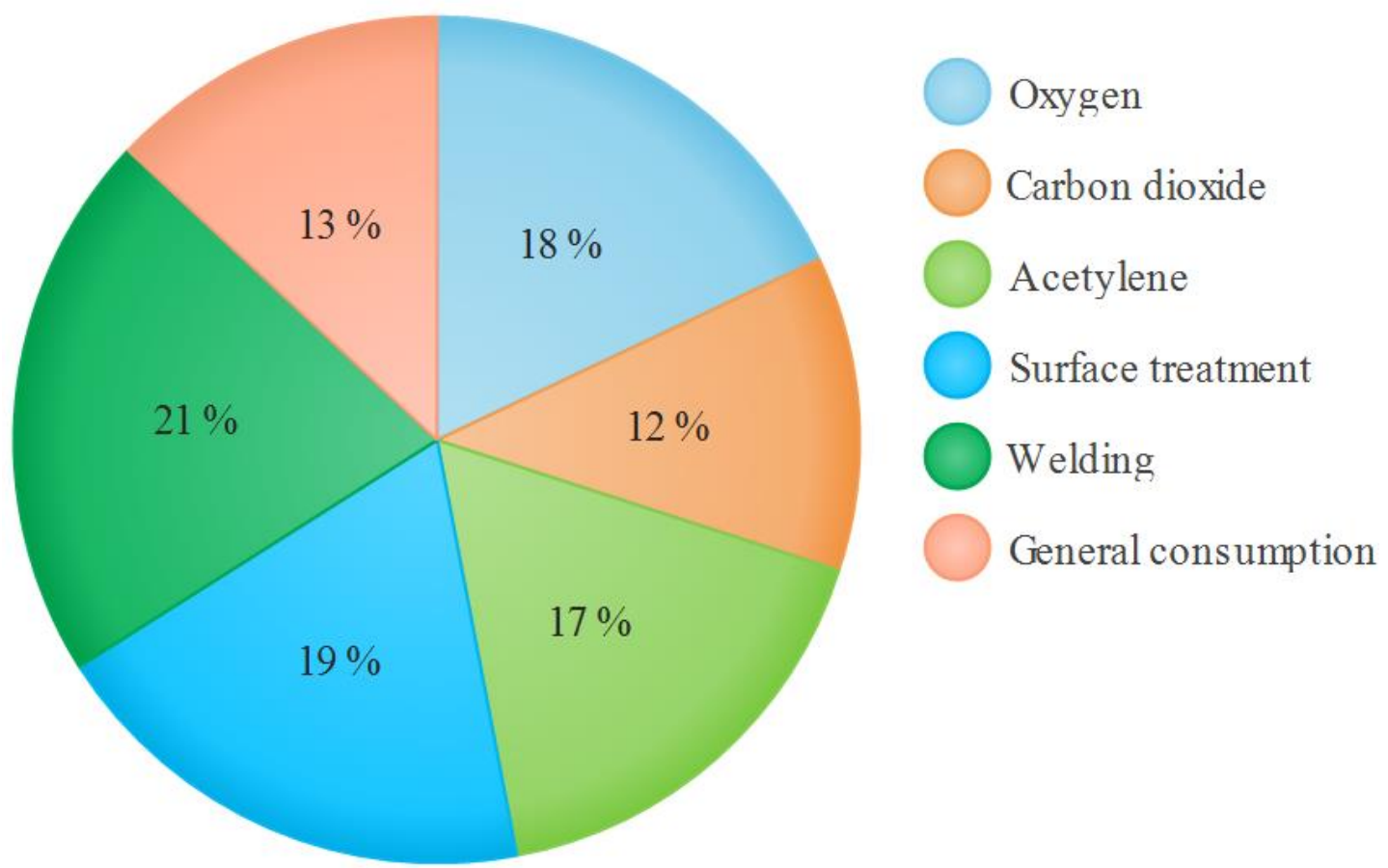

Fig. 2 Share in the electricity consumption, [23]

While this overview provides guidelines about the structure of the total energy consumption for a typical shipyard, this statistics may vary for various shipyards depending on a particular production program, order book state, ship complexity and state of production lines. Nevertheless, the general approach developed for this typical shipyard may be well adopted for any shipyard by taking into account its particular electricity demand. 


\section{Renewable energy sources appropriate for ship production}

Current development and application of renewable energy sources for ship production is mainly driven by several factors, i.e. increasing energy production demands, increasing awareness of conventional sources impact on climate change and strong ambition to exploit huge, unused and renewable energy potentials. In general, renewable energy sources are classified as bioenergy, solar energy, geothermal energy, hydropower, ocean energy and wind-energy sources, e.g. [5]. These renewable energy sources can be onshore and offshore.

Having in mind a rather complex nature of ship-production process, heavily exploited shipyard area and complex geographical placement, while assuming that renewable energy source is to be placed within the shipyard and managed by its personnel, only solar, ocean and wind energy sources are considered suitable. Therefore, the main properties of those particular renewable energy sources relevant for this study are briefly outlined.

\subsection{Photovoltaic electricity generation}

In comparison to other renewable energy sources, the solar energy is considered the cleanest and most abundant. It has an inexhaustible capacity of more than $1.5 \cdot 10^{18} \mathrm{kWh}$ annually, [5]. It enables noiseless, carbon free and rather simple electricity production.

The most effective way to exploit solar energy is based on photovoltaic effect. This includes a direct conversion of solar input into electricity. Photovoltaic systems are composed of quite simple and easy-to-maintain devices that are widely applicable, from hand-size systems with output in microwatts up to large industrial and space applications and power plants with capacities in megawatts, e.g. [24]. Consequently, extensive experience in this field of renewable energy is gained mainly due to its steady development, its superior availability, cost effectiveness, capacity and efficiency, [25].

Commonly used technical solutions involve photovoltaic module, inverter, energy storage, energy consumer, and connection to electrical network to balance electricity deficiency and excess, Fig. 3. They can be arranged as stand-alone or hybrid systems combining solar power with other conventional or renewable energy sources. Light absorbing material is of particular importance for cell efficiency. Monocrystalline and multi-crystalline silicon technology is developed along with new concepts using amorphous and crystalline silicon, organic and thin film cells with typical efficiency of approximately 19\%, e.g. [24].

The development in photovoltaic technology is accompanied by regulatory instruments, educational activities, as well as by financial and environmental initiatives aiming towards successful and rapid implementation of solar energy into energy systems.

It is estimated that solar electricity will have about $11 \%$ share of the world energy supply by the year 2050. This will positively influence photovoltaic industry resulting in a decrease in installation and maintenance costs, [26]. Current installation costs are estimated to be around $2.5 \$ / \mathrm{W}$ with a goal to reduce them to $1 \$ / \mathrm{W}$ until 2020 due to innovation and production development. Annual operative and maintenance costs for such a system are approximately $1.5 \%$ of the investment cost, [5]. 


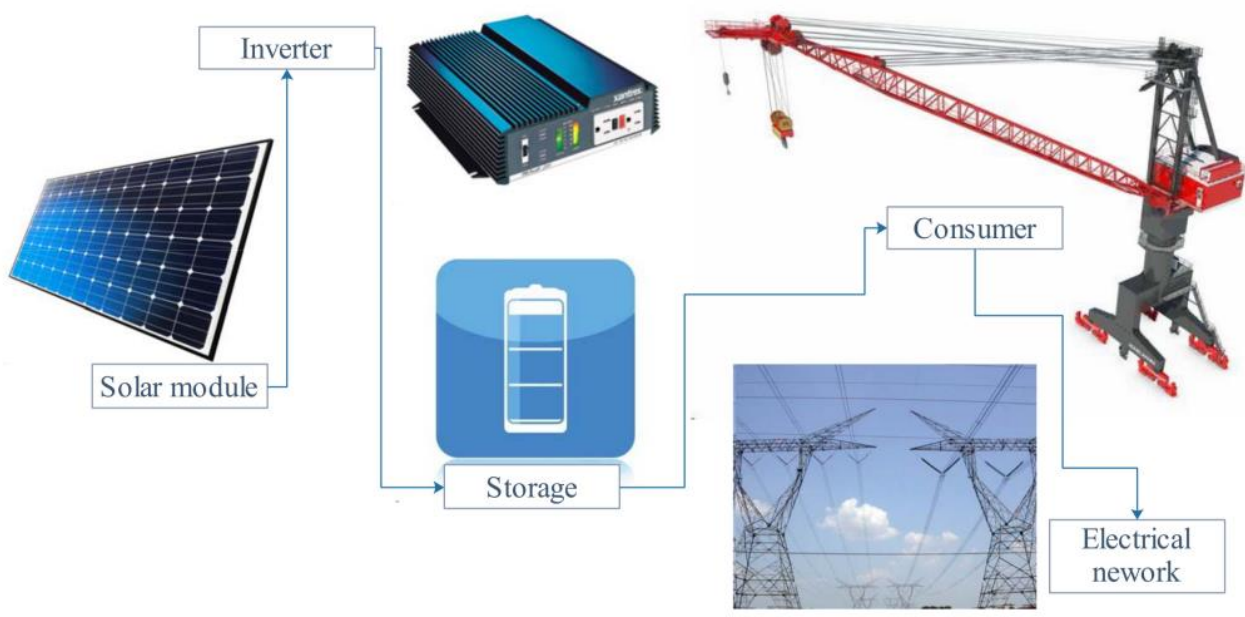

Fig. 3 Schematic view of a typical solar system

The motivation for such a rapid development in high-end technology is obtained through international and national activities. They enable long-term targets and policies to be achieved by creating favorable and stable business climate that attracts investments in manufacturing, research and development activities. Some nations like Spain, Germany, United States, Brazil, Japan and China currently play a leading role in application of photovoltaic electricity generation with prominent implementations like building integrated systems as shading devices, [27], vertically positioned power sources in opaque building surfaces, [28], desalination plants, [29], Earth orbiting solar power satellite, [30], home and pumping systems, [31], and solar power plants, [32].

\subsection{Ocean energy}

Total annual energy capacity of ocean energy sources is estimated to be about $2 \cdot 10^{15}$ $\mathrm{kWh},[5]$. This is approximately $0.13 \%$ of the available solar energy. At this moment, ocean energy sources are barely harvested, mainly due to development and conceptual stage of this technology based on ocean energy converters typically sighted near the coast line or at the open sea, [33]. A typical system consists of hydrokinetic devices that transform sea current and wave kinetic energy into electricity. Some solutions make use of a salinity gradient and thermal energy of the sea. With respect to ocean energy sources, a development of these complex subsea structures with low production rate is currently addressed, e.g. [5].

At this point, research and development of hydrokinetic devices is dominated by small companies producing design solutions at high readiness level, [34]. Currently, there are three typical hydrokinetic devices, i.e. axial-flow, cross-flow, and oscillating systems. Their prototypes commonly have the power output up to $2 \mathrm{MW}$. Some locations where those hydrokinetic devices are used in water depths up to $35 \mathrm{~m}$ include United Kingdom, Ireland, Scotland, France, Spain, China, Japan, South Korea, Canada and United States, [35].

Axial and cross-flow hydrokinetic devices operate as lift-based systems similar to wind turbines and aircraft wings. Rotational motion about the axial or transversal axis is induced by torque as a combination of drag and lift forces acting on a blade composed of twodimensional hydrofoil cross-sections, e.g. [36], Fig. 4. Current intensive development of liftbased hydrokinetic devices is based on favorable flow properties like a significant kinetic energy density across the rotor-disc area, simple manufacturing, handling, transport, installation and maintenance, as well as mitigation of visual pollution and sea routes. 


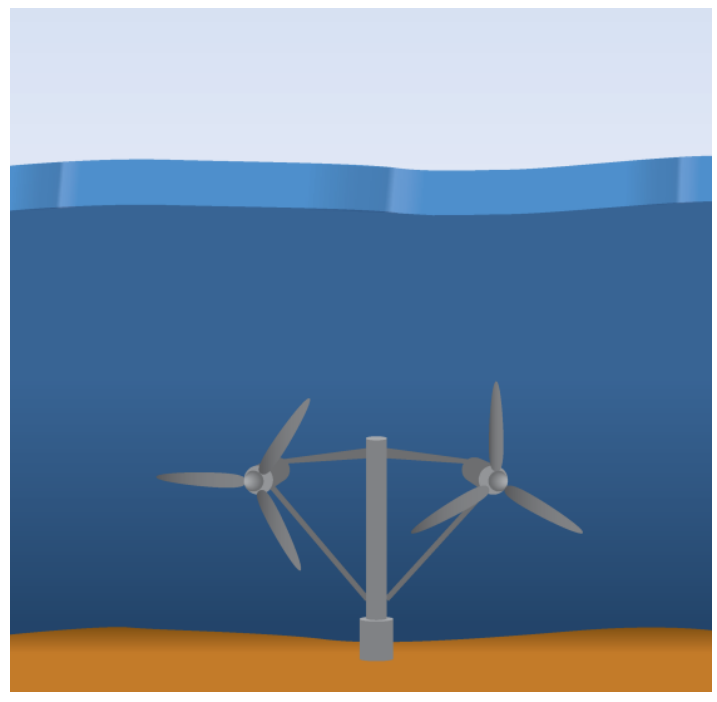

a)

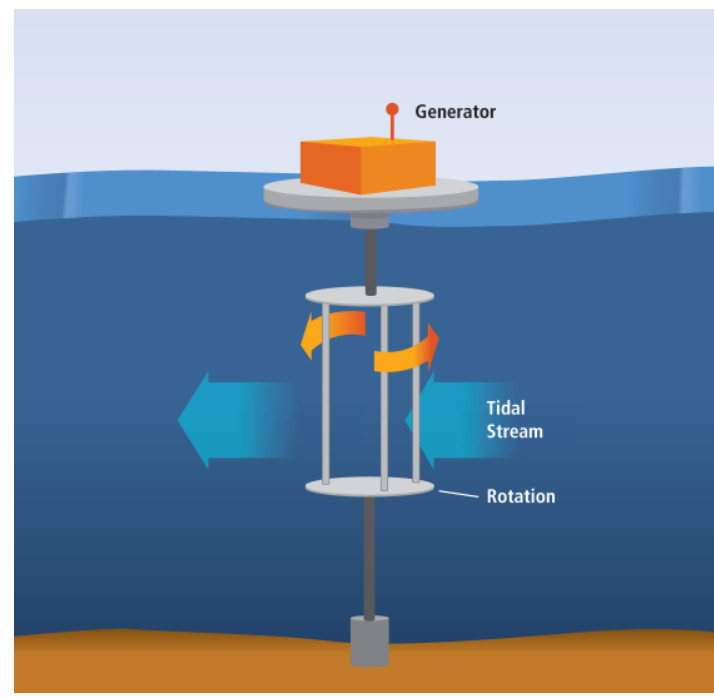

b)

Fig. 4 An example of tidal turbine in a) axial flow and b) cross flow arrangement, [5]

What makes this renewable energy source particularly attractive is the fact that sea currents are highly predictable, which simplifies their design and ensures favorable working conditions. Some drawbacks are related to corrosive sea environment, sea fouling, nonuniform velocity profile of sea currents due to a friction between the sea flow and the sea bottom, as well as possible creating of underwater noise, e.g. [6].

Various types of oscillating systems are developed for a wide range of operating conditions in order to convert wave or flow vortex energy into electricity. They typically consist of three components, i.e. primary interface that interacts with fluid and transfers its energy to the second subsystems that incorporates a direct drive or serves as a short-term energy storage. The third interface converts energy by means of electromechanical processes, [5].

Wave energy converters differ from one another primarily with respect to the type of their interaction with the wave motion (heaving, surging, pitching), as well as with respect to the water depth and distance from the shore, [37]. Principal methods of energy conversion are oscillating water columns, oscillating body systems and overtopping devices, Fig. 5.

Oscillating water column devices, Fig. 5a, convert wave energy by means of varying air pressure induced by wave motion. Air flows through an air turbine, thus inducing its rotation. Consequently, this kinetic energy is transformed into electricity.

Oscillating body system, Fig. 5b, also known as the point absorber, transforms waveinduced heave motion into electricity by means of a relative motion among two bodies.

A prominent example of an energy storage conversion system is an overtopping device, Fig. 5c. Its basic operational principle is transformation of wave kinetic energy into potential by means of water accumulation. Once accumulated, the water is drained through the hydraulic turbine to induce its rotational motion. 


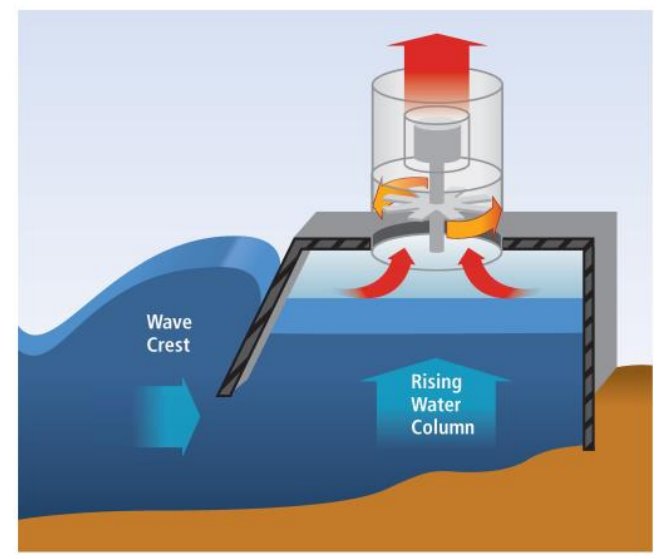

a)

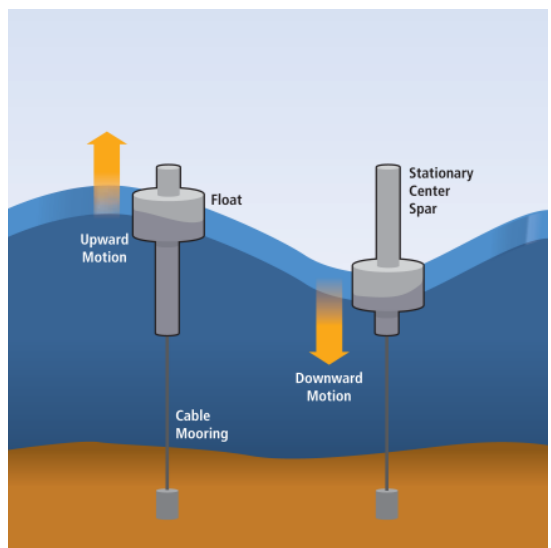

b)

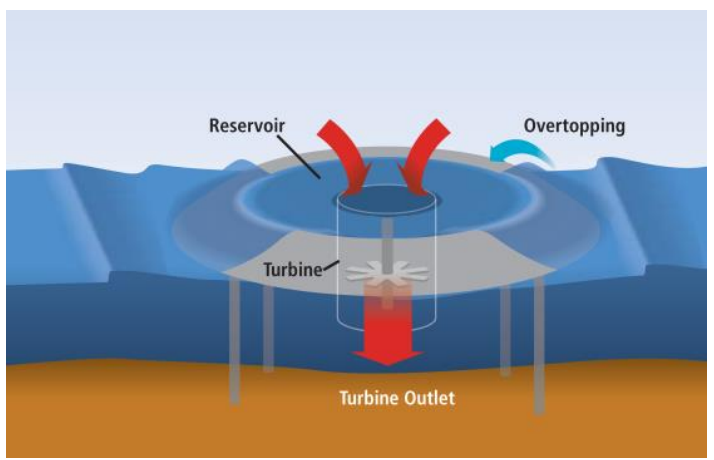

c)

Fig. 5 Oscillating systems: a) oscillating water column, b) oscillating body and c) overtopping device, [5]

An interesting concept of oscillating system based on vortex-induced vibration (VIV) is briefly outlined in [34]. Its operating principle is based on shedding vortices that form a characteristic von Kármán street in the wake of the body. This includes alternating lowpressure regions and consequently periodic lifting force acting as vibration excitation. This energy due to vibrations is harvested using linear power-take-off elements. An important advantage of this oscillating system in comparison with lift-based systems is its ability to exploit slow water flows with a sea-current speed as low as $0.4 \mathrm{~m} / \mathrm{s}$, [38].

Current research in generating ocean renewable energy by using hydrokinetic systems is focused on a) development of resource assessment methodologies, b) advanced turbine design with particular emphasis on efficient blade development, turbine wake and array modeling, and c) environmental and biodiversity impacts, [39]. A considerable discrepancy in investment price for hydrokinetic devices from $4500 \$ / \mathrm{kW}$ to $14300 \$ / \mathrm{kW}$, [6] enables a wide range of practical solutions.

\subsection{Wind energy}

Global annual wind energy capacity is estimated at $1.662 \cdot 10^{15} \mathrm{kWh}$, [5], which is approximately $0.11 \%$ of the available solar energy. Onshore and offshore wind-energy harvesting is predominantly developed in Denmark, Spain, Germany, Sweden, United Kingdom, and United States of America. Typical solution is horizontal-axis wind turbine that transforms wind flow into rotational motion and then into electricity. A typical power output of these wind turbines is up to $8 \mathrm{MW}$ of installed power. This enables satisfying energy demand for more than 10,000 homes, [40]. Commonly installed power is between $2 \mathrm{MW}$ and $4 \mathrm{MW}$, similar for both onshore and offshore wind farms. 
A typical onshore and offshore wind-turbine structure consists of tower, rotor, and nacelle with installed power take-off system. While the onshore wind turbines are fixed to the ground, the offshore wind turbines can be fixed to the sea bottom or placed at the characteristic offshore platforms. For the fixed offshore wind turbine, the wind turbine is placed at a fixed monopile, gravity-base or jacket supporting structure. For the floating offshore wind turbine, the floating structures include spar, tension leg or semisubmersible supports, [41].

In comparison to an onshore wind turbine, an offshore wind turbine has some favorable properties like nearly constant average velocity at the hub height, weaker atmospheric turbulence, lower structural fatigue, possibility to install longer blades and consequently create larger power output. However, some drawbacks are mainly related to maintenance, sea loading and harsh sea environment, [42].

Once built, offshore wind turbine has to be successfully installed and maintained within harsh sea environment which turns out to be quite a demanding task, [43]. Moreover, its operation properties and output have to be continuously monitored for a long period that can be accomplished only by applying specific data integration framework optimized towards recovery rate improvement, [44]. It is also important to emphasize an increase of activities related to offshore wind farming in the Adriatic Sea, [45], which could act as a leaver significantly influencing a development of the Croatian economy, [46].

Current research is mainly focused on wind-turbine and wind-power-plant design and optimization, advanced telescopic and self-erecting towers, application of advanced materials enabling longer, lighter and more elegant blades that enhance efficiency and power output of wind turbines. An important and still open issues are related to wind characteristics around wind turbines placed in topographically complex terrain, [47], and in regions characterized by non-standard transient winds, [48], particularly in case of extreme weather conditions encountered during summer, [49], and winter, [50]. These untypical wind conditions can considerably increase structural fatigue of wind turbines and thus shorten their lifetime, while the power output of wind turbines in these transient wind conditions is smaller than it is the case for quasi-steady flow conditions.

A particular focus is on development of offshore floating wind turbines in order to decrease their installation and maintenances cost, develop methodologies to address coupled hydro-structural issues, develop turbine-transportation and offshore-assembly operations. The cost of onshore and fixed offshore wind turbines is estimated to be between $2000 \$ / \mathrm{kW}$ and $5000 \$ / \mathrm{kW}$ with annual operative and maintenance costs ranging from $170 \$ / \mathrm{kW}$ to 350 $\$ / \mathrm{kW},[5]$.

A comparison of costs for the solar, ocean and wind renewable energy sources is reported in Table 1.

\section{The Croatian shipyard case study}

Ship production industry in Croatia encompasses 5 large, 14 medium and 352 small shipyards that produce, maintain and repair ships and offshore structures. They employ approximately 20000 personnel and create an annual income of approximately 1.3 billion $\$$, [51]. Croatian shipyards are considered to be an industrial primemover, as they enhance regional community development with multiplicative factor of about 2.8, [52]. Moreover, 5\% of the total Croatian industry income is generated by shipyards' export, thus contributing annually with 0.8 billion $\$$ to the national GDP. 
Table 1 A comparison of considered renewable energy sources with respect to their commonly installed power and installation and maintenance costs, [5]

\begin{tabular}{l|l|llll} 
Source & & $\begin{array}{l}\text { Commonly } \\
\text { power, } \mathrm{kW}\end{array}$ & $\begin{array}{l}\text { installed } \\
\text { Investment cost, } \\
\$ / \mathrm{kW}\end{array}$ & $\begin{array}{l}\text { Annual maintenance } \\
\text { cost, \$/kW }\end{array}$ \\
\hline \multirow{2}{*}{ Solar } & Photovoltaic modules & $\begin{array}{l}\text { Microwatts } \\
\text { Megawatts }\end{array}$ & to & 2500 & 35 \\
& Tidal turbine & 2000 & $4500-14300$ & $100-140$ \\
Ocean & 750 & $6200-16100$ & 180 \\
& Oscillating systems & NA & NA & NA \\
& VIV oscillating systems & NA & 2000 & $170-350$ \\
\multirow{5}{*}{ Wind } & Onshore turbine & $2000-4000$ & $2000-5000$ & $175-350$ \\
& Offshore fixed turbine & $2000-4000$ & NA & NA
\end{tabular}

The largest Croatian shipyards, and thus the largest energy consumers, are located in Croatian coastal cities of Pula, Rijeka, Split and Trogir, Fig. 6. They manufacture custommade bulk carriers, chemical and oil tankers, car and wagon carriers, heavy lifters, passenger ferries, submarines, and dredgers. The Croatian shipbuilding industry, although relatively minor player at the global scene, plays a significant role in the total EU context with $27 \%$ of share in new orders, $14 \%$ in order book and $12 \%$ in deliveries.

Furthermore, a ratio between the total number of compensated gross tons (CGT) and the gross tons (GT) is approximately equal to one, thus indicating a high complexity of produced ships. It is important to mention that this matches the capability to produce the most complex ships of the world leading shipbuilding nations like China, Japan, and South Korea. An average annual production of Croatian shipyards is approximately 15 ships, [53]. At the moment, the entire production of Croatian shipyards is based on conventional energy sources.

This methodology is developed on example of a typical Croatian shipyard Uljanik, Fig. 1. It is based on the analyzed energy demands and possible renewable energy technology

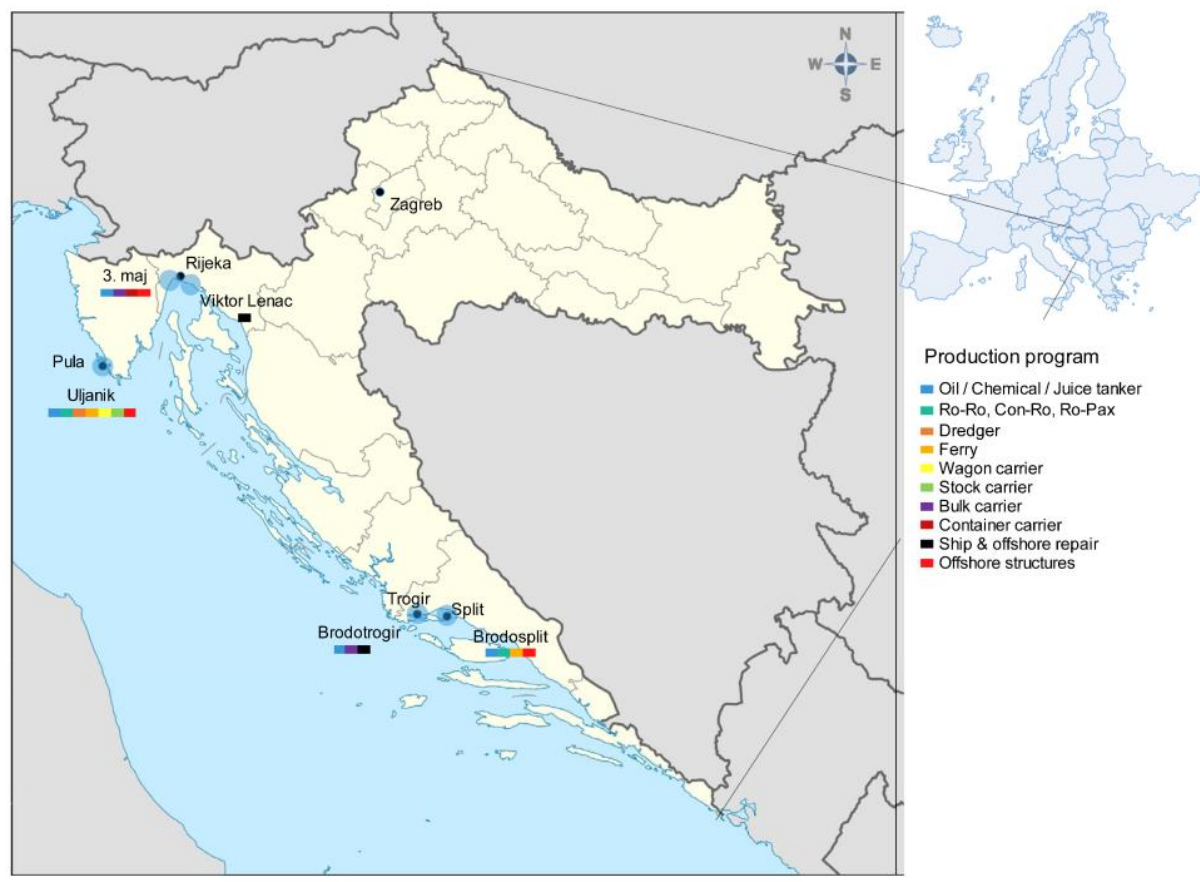

Fig. 6 Geographical position and typical production program of large Croatian shipyards, [52] 
implementations for shipyard production. In case it is anticipated that in average a typical Croatian shipyard annually produces up to 5 ships of 5000 lightweight tons, the total annual electrical energy consumption is approximately $19 \mathrm{GWh}$. For the purposes of this study, the total annual electrical energy consumption can be approximated with $20 \mathrm{GWh}$ per year in accordance with e.g. [54].

Since some of the considered technologies are still insufficiently developed, the present case study is focused on application of mature solutions, i.e. photovoltaic modules, horizontal-axis tidal turbines and fixed offshore wind turbines. For this purpose, solar, sea current, and wind potentials are specified for the studied local environment.

Croatia is considered to be among the top insolated EU countries with approximately $4.2 \mathrm{kWh} / \mathrm{m}^{2}$ to $5.2 \mathrm{kWh} / \mathrm{m}^{2}$ of average daily insulation. The most significant solar potential in Croatia is at the Adriatic Coast. It is annually from $1.45 \mathrm{MWh} / \mathrm{m}^{2}$ to $1.60 \mathrm{MWh} / \mathrm{m}^{2}$, [45] and [55], for a horizontal insolated area, Fig. 7. The required area of a solar system is determined as a ratio between the energy demand, $E_{D}=20 \mathrm{GWh}$, and energy supply, $E_{S}=1.45$ $\mathrm{MWh} / \mathrm{m}^{2}$, whereas the transformation efficiency $\eta=0.19$ needs to be taken into account, [5].

In this case, the required area is approximately equal to $0.073 \mathrm{~km}^{2}$, where approximately 36300 units of $2 \mathrm{~m}^{2}$ solar panels can be placed. In general, solar panels in shipyards can be conveniently placed at flat building roofs. A single panel can therefore annually produce $0.551 \mathrm{MWh}$ of energy.

An annual average of approximately 2000 sunny hours is taken into account, [56], whereas an installed single solar panel power yields about $275 \mathrm{~W}$, i.e. $10 \mathrm{MW}$ in total. Based on the required installed power, an investment cost is determined using the data reported in Table 1 as 25 million $\$$ that is approximately 6.25 times more than the cost of the estimated

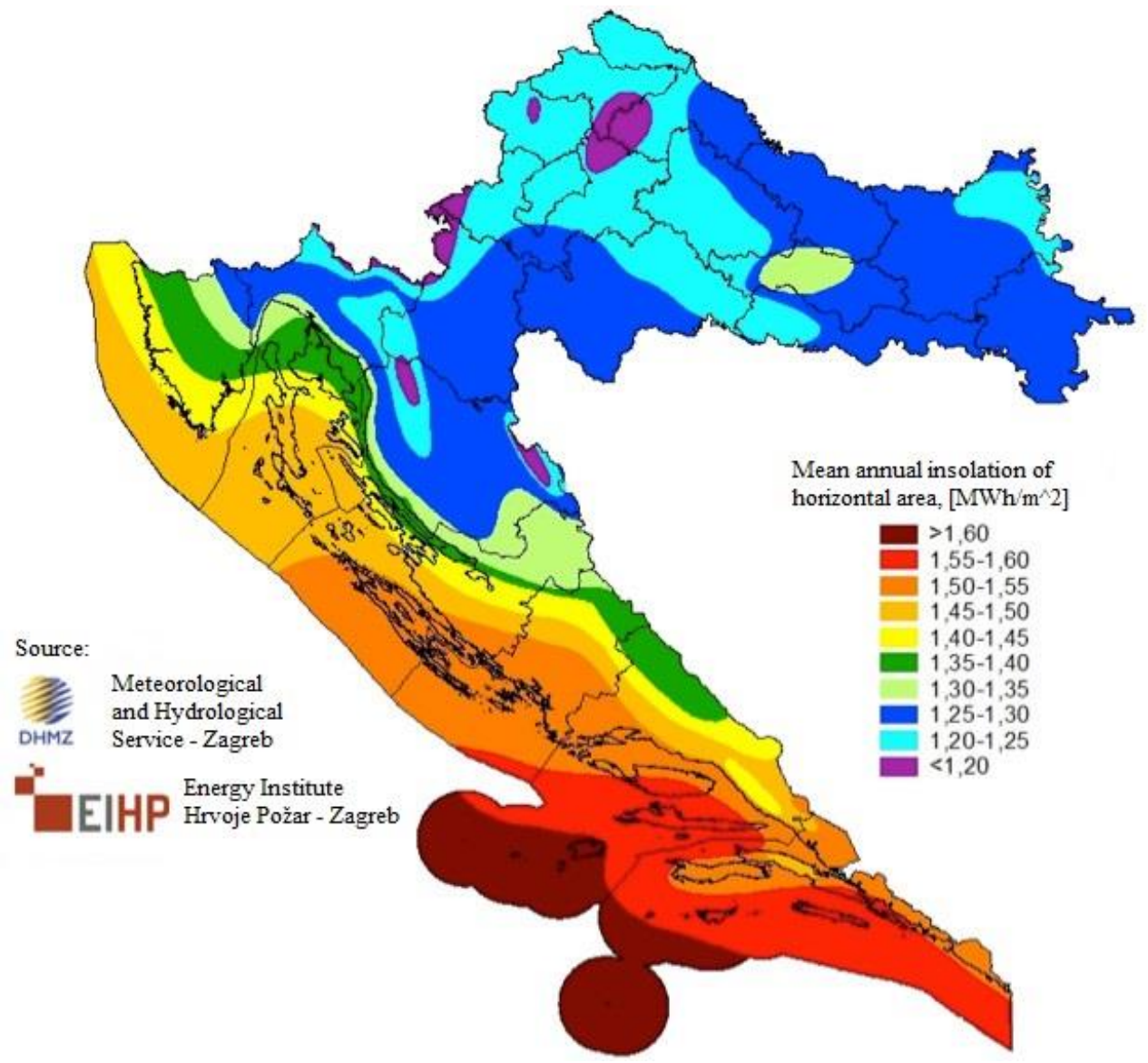

Fig. 7 Average annual insolation for Croatia, adapted from [45] 
$20 \mathrm{GWh}$ of the annual energy consumption, in case a typical electrical energy cost in Croatia of approximately $0.2 \$ / \mathrm{kWh}$ is considered, [57].

Therefore, taking into account the maintenance costs, a return period can be estimated to be approximately 7 years. Moreover, the return period can be additionally reduced if the Environmental Protection and Energy Efficiency Found (EPEEF) investment co-funding up to $40 \%$ of the expenses is included, [58].

A possibility for renewable energy production using hydrokinetic and aerokinetic devices is analyzed in [6] with respect to renewable energy potentials of sea currents and wind at the Adriatic Sea. It is estimated that a single horizontal-axis tidal turbine is able to annually produce approximately 4.5 MWh of electrical energy, whereas a wind turbine yields approximately $4 \mathrm{GWh}$ for the same period. An estimated energy output is rather low, mainly due to small wind and sea current velocities that results with rather low efficiency of the installed capacities.

Consequently, an installation of horizontal-axis tidal turbines for annual production of $20 \mathrm{GWh}$ does not seem to be a realistic solution, particularly if the installation cost of approximately 4450 turbines is considered.

On the other hand, the same energy can be produced using 5 wind turbines of installed power of $5 \mathrm{MW}$. In this case, the investment price is about 50 million $\$$, while the return period is twice as long as it is the case for the solar panels. Moreover, further analysis of wind potential at the Adriatic Sea will result with more reliable data.

\section{Impact on energy, environment and shipyard business}

Application of renewable energy sources for purposes of ship production leads to implementation of green production principles promoted by UN. This approach promotes green and environment-friendly shipbuilding industry. As ship production is considered to be a significant industrial component and large energy consumer, an approach outlined in the present study contributes to reduction in greenhouse gas emission.

According to a current Eurostat database, manufacturing and electricity, gas steam and air conditioning in 2013 participate with $45.4 \%$ in total greenhouse gas emissions, [59]. Such a significant share can be effectively decreased by applying renewable energy sources in production process. Namely, according to National Energy Technology Laboratory, [60], $\mathrm{CO}_{2}$ emission rates in case of electricity generation using coal and natural gas are approximately $1000 \mathrm{~g} / \mathrm{kWh}$ and, respectively $450 \mathrm{~g} / \mathrm{kWh}$, yielding between 9000 and $20000 \mathrm{t}$ less $\mathrm{CO}_{2}$ emission annually only due to application of renewable energy sources in the analyzed Croatian shipyard (Uljanik).

Along with that, one of the immediate factors of introducing green shipbuilding concept is increasing the shipyard profitability, which is strongly enhanced by such an approach. Application of renewable energy sources in shipyards significantly improves their energy efficiency, sustainability, and operational effectiveness (particularly in case of transport) with a final consequence of an increased profitability.

A decreased shipyard share in greenhouse gas emission promotes its significance at a local, state and global level, particularly as such activities are generally well accepted in public. Therefore, a ship produced using renewable energy is to be considered as a novel product, which is completely designed, developed and manufactured without a significant change in current ship production procedures. In such a way, shipyards will gain modern and competitive production program which, will be attractive for ship owners and investors. 
Based on the outlined benefits, a shipyard has an opportunity to strengthen an advance its position during negotiation with national or supranational governments and investors. A set of anticipated immediate and mediate effects is reported in Table 2.

Table 2 A summary of immediate and mediate benefits of introducing renewable energy sources in shipbuilding process

\begin{tabular}{|c|c|}
\hline \multicolumn{2}{|c|}{ RENEWABLE ENERGY IN SHIPBUILDING PRODUCTION } \\
\hline IMMEDIATE BENEFITS & MEDIATE BENEFITS \\
\hline $\begin{array}{l}\text { - } \text { Profit } \\
\text { - Energy efficiency } \\
\text { - Operational effectiveness } \\
\text { - Sustainability }\end{array}$ & $\begin{array}{l}\text { - } \text { Public perception } \\
\text { - New product } \\
\text { - } \text { Competitive product } \\
\text { - Negotiations with investors }\end{array}$ \\
\hline
\end{tabular}

\section{Conclusion}

Shipbuilding industry is globally considered as one of the key industries. It has a significant electrical energy demand that is required for production purposes. In such a way the shipbuilding industry considerably and adversely contributes to the overall $\mathrm{CO}_{2}$ emission and global warming. To diminish this adverse effect on the energy and the environment, various measures with respect to energy efficient equipment and ship engines are adopted. Nevertheless, a serious lack of initiatives in view of energy consumption in ship production process and its environmental impact is noticed.

The present study thus focuses on developing an approach that outlines possibilities with respect to introducing sustainable renewable energy systems in ship production industry. While this hypothesis is studied on example of a typical Croatian shipyard, the general findings are expected to be widely applicable by taking into account particularities of any other shipyard.

The analysis is performed for solar panels, tidal and wind turbines. The focus is on their technology readiness, investment costs, and the total energy demand. For the studied case, the solar panels are selected as the most suitable renewable technology with the investment return period of approximately seven years.

The analysis clearly outlines beneficial effects of the green shipbuilding approach on the energy, environment and the shipyard business in general, while there is a number of other favorable immediate and mediate effects, e.g. profitability, sustainability, energy efficiency, operational effectiveness, positive public perception, new and competitive products, favorable position in deal making with investors.

\section{Acknowledgment}

The Croatian Science Foundation HRZZ-IP-2016-06-2017 (WESLO) support is gratefully acknowledged. 


\section{REFERENCES}

[1] Marine Environment Protection Committee (MEPC). Standard specification for shipboard incinerators, International Maritime Organization, London, April 2014.

[2] Marine Environment Protection Committee (MEPC). Amendments to MARPOL Annex VI, International Maritime Organization, London, April 2016.

[3] Council Working Party on Shipbuilding. Peer Review of Japanese Government Support Measures to the Shipbuilding Sector, OECD, Paris, 2012.

[4] United Nations - Industrial Development Organization (UNIDO). A Greener Footprint for Industry Opportunities and challenges of sustainable industrial development, UNIDO, Vienna, 2010.

[5] Edenhofre O., Pichs-Madruga R., Sokona Y., Seyboth K., Matschoss P., Kadner S., Ywickel T., Eickemeier P., Hansen G., Schlömer S.,Von Stechow C., editors. IPCC Special Report on Renewable Energy Sources and Climate Change Mitigation, Cambridge University Press, Cambridge, United Kingdom, 2011. https://doi.org/10.1017/CBO9781139151153.

[6] Hadžić N., Kozmar H., Tomić, M. Offshore renewable energy in the Adriatic Sea with respect to the Croatian 2020 energy strategy. Renewable and Sustainable Energy Reviews, 40, 2014, pp. 597-607. https://doi.org/10.1016/j.rser.2014.07.196.

[7] http://ec.europa.eu/priorities/energy-union-and-climate en (Accessed on 6 September 2016.)

[8] Ministry of economy, labor and entrepreneurship of the Republic of Croatia. Energy strategy of the Republic of Croatia, Zagreb 2009.

[9] Song J., Yang W., Higano Y., Wang X. Introducing renewable energy and industrial restructuring to reduce GHG emission: Application of a dynamic simulation model, Energy Conversion and Management, 96 (2015), pp. 625-636. https://doi.org/10.1016/j.enconman.2015.03.024.

[10] Shin Y.H, Tseng C.H. Cost-benefit analysis of sustainable energy development using life-cycle cobenefits assessment and he system dynamics approach, Applied Energy, 119 (2014), pp. 57-66. https://doi.org/10.1016/j.apenergy.2013.12.031.

[11] Skea J., Nishioka S. Policies and practices for a low-carbon society, Climate policy, 8 (2008), pp. S5S16. https://doi.org/10.3763/cpol.2008.0487.

[12] Yamashita M. Roadmap to a low-carbon world: business perspectives, Symposium on Roadmap to a low-carbon world 2008, Tokyo.

[13] White H. Changing energy consumption: why it happens and how it can be made happen, Symposium on Achieving a Low-Carbon Society 2007, London.

[14] Fais B., Sabio N., Strachan N. The critical role of the industrial sector in reaching long-term emission reduction, energy efficiency and renewable targets, Applied Energy, 162 (2016), pp. 699-712.

[15] Dai H., Xie X., Xie Y., Liu J., Masui T. Green growth: The economic impacts of large-scale renewable energy development in China, Applied Energy, 162 (2016), pp. 435-449. https://doi.org/10.1016/j.apenergy.2015.10.049.

[16] Wu J., Wang R., Pu G., Qi H. Integrated assessment of exenergy, energy and carbon dioxide emissions in an iron and steel industrial nework, Applied Energy, 183 (2016), pp. 430-444. https://doi.org/10.1016/j.apenergy.2016.08.192.

[17] Zhang Q., Zhao X., Lu H., Ni T., Li Y. Waste energy recovery and energy efficiency improvovement in China's iron and steel industry, Applied Energy, 191 (2017), pp. 502-520. https://doi.org/10.1016/j.apenergy.2017.01.072.

[18] Zhang B., Qu X., Meng J., Sun X. Identifying primary energy requirements in structural path analysis: A case study of China, Applied Energy 191 (2017), pp. 425-435. https://doi.org/10.1016/j.apenergy.2017.01.066.

[19] Rudberk M., Waldemarsson M., Lidestm H. Strategic perspectives on energy management: A case study in the process industry, Applied Energy 104 (2013), pp. 487-496. https://doi.org/10.1016/j.apenergy.2012.11.027.

[20] Shirazi S.Z., Shirazi S.M.Z. Review of Spanish renewable energy policy to encourage investment in solar photovoltaic, Journal of Renewable and Sustainable Energy 4 (2012).

[21] Aslani A., Antila E., Wong K.F.V., Comparative analysis of energy security in the Nordic countries: The role of renewable energy sources in diversification, Journal of Renewable and Sustainable Energy 4 (2012). 
[22] Storch R.L., Hammon C.P., Bunch H.M., Moore R.C. Ship production. The Society of Naval Architects and Marine Engineers, New Jersey, 1995.

[23] Harish C.R., Sunil S.K. Energy Consumption and Conservation in Shipbuilding. International Journal of Innovative Research and Development, July, 2015.

[24] Parida B., Iniyan S., Goić R. A review of solar technologies. Renewable and Sustainable Energy Reviews, 15, (2011), pp. 1625-1636. https://doi.org/10.1016/j.rser.2010.11.032.

[25] Kannan N., Vakeesan D. Solar energy for the future world: - A review. Renewable and Sustainable Energy Reviews 62, (2016), pp. 1092-1105. https://doi.org/10.1016/j.rser.2010.11.032.

[26] Dincer F. The analysis on photovoltaic electricity generation status, potential and policies of the leading countries in solar energy. Renewable and Sustainable Energy Reviews, 15, (2011), pp. 713-720. https://doi.org/10.1016/j.rser.2010.09.026.

[27] Yoo S.H., Lee E.T. Efficiency characteristics of building integrated photovoltaics as a shading device. Building and Environment 37, (2002), pp. 615-623. https://doi.org/10.1016/S0360-1323(01)00071-3.

[28] Ordenes M., Marinoski D.L., Braun P., Ruther R. The impact of building-integrated photovoltaics on the energy demand of multi-family dwellings in Brazil. Energy and Buildings, 39, (2007), pp. 629-642. https://doi.org/10.1016/j.enbuild.2006.10.006.

[29] Lamei A., Van der Zaag P., Von Munch E. Impact of solar energy cost on water production cost of seawater desalination plants in Egypt. Energy Policy, 36, (2008), pp. 1748-1756. https://doi.org/10.1016/j.enpol.2007.12.026.

[30] Seboldt W., Klimke M., Leopold M., Hanoeski N. European sail tower SPS concept. Acta Astronautica 48, (2001), pp. 785-792. https://doi.org/10.1016/S0094-5765(01)00046-7.

[31] Pande P.C., Singh A.K., Ansari S., Vyas S.K., Dave B.K. Design development and testing of a solar PV pump based on drip system for orchards. Renewable Energy, 28, (2003), pp. 385-396. https://doi.org/10.1016/S0960-1481(02)00037-X.

[32] http://www.chinadaily.com.cn/m/powerchina/2014-01/02/content 17210451.htm (Accessed on October 28 2016)

[33] Ben Elghali S.E., Bendouzid M.E.H., Charpentier J.F. Marine Tidal Current Electric Power Generation Technology: State of the Art and Current Status. IMDC, Antalya, 2007, pp. 1407-1412.

[34] Laws N.D., Epps, B.P. Hydrokinetic energy conversion: Technology, research and otlook. Renewable and Sustainable Energy Reviews 57, (2016), pp. 1245-1259. https://doi.org/10.1016/j.rser.2015.12.189.

[35] Brennan F.P., Falzarano J., Gao Z., Landet E., Le Boulluec M., Rim C.W., et al. Offshore renewable energy. In: Fricke W, Bronsart R, editors. $18^{\text {th }}$ International Ship and Offshore Structure Congress (ISSC 2012), Schiffbautechnische Gesellschaft, Hamburg, 2012, Vol. 2, pp. 153-199.

[36] Hadžić N., Tomić M., Senjanović I. Harmonic loading of horizontal axis tidal turbine due to nonuniform stream profile. Ocean Engineering, $91 \quad$ (2014), pp. 196-207. https://doi.org/10.1016/j.oceaneng.2014.09.007.

[37] Guedes Soares C., Bhattacharjee J., Karmakar D. Overview and prospectives for development of wave and offshore wind energy. Brodogradnja/Shipbuilding, 65 (2014), pp. 87-109.

[38] Chang C.C. Hydrokinetic energy harvesting using the vivace converter with passive turbulence control. In: Proceedings of the ASME $201130^{\text {th }}$ international conference, offshore and Arctic engineering, 2011.

[39] Uihlein A., Magagna D. Wave and tidal current energy - A review of the current state of research beyond technology. Renewable and Sustainable Energy Reviews 58, (2016), pp. 1070-1081. https://doi.org/10.1016/j.rser.2015.12.284.

[40] http://www.dailymail.co.uk/sciencetech/article-3658712/A-mighty-wind-Work-begins-world-s-biggestturbine-dwarf-London-Eye.html. (Accessed on November 19 2016)

[41] Zhang J., Fowai I., Sun K. A glance at offshore wind turbine foundation structures, Brodogradnja/Shipbuilding 67, (2016), pp. 101-113.

[42] Bilgili M., Yasar A., Simsek E. Offshore wind power development in Europe and its comparison with onshore counterpart. Renewable and Sustainable Energy Reviews, 15, 2011, pp. 905-915. https://doi.org/10.1016/j.rser.2010.11.006.

[43] Parveen R., Kishor N., Mohanty S.R. Off-shore wind farm development: Present status and challenges. Renewable and Sustainable Energy Reviews, 29, 2014, pp. 780-792. https://doi.org/10.1016/j.rser.2013.08.108. 
[44] Nguyen T.H., Prinz A., Friisø T., Nossim R., Tyapin I. A framework for data integration of offshore wind farms. Renewable Energy 60, 2013, pp. 150-161. https://doi.org/10.1016/j.renene.2013.05.002.

[45] Croatian Academy of Science and Arts. Croatian Natural Resources, Croatian Academy of Science and Arts, Zagreb, 2016. (In Croatian)

[46] Liščić B., Senjanović I., Većeslav Č., Kozmar H., Tomić M., Hadžić N. Offshore Wind Power Plant in the Adriatic Sea: An Opportunity for the Croatian Economy, Transactions of Maritime Science 2 (2014), pp. 103-110. https://doi.org/10.7225/toms.v03.n02.001.

[47] Kozmar H., Allori D., Bartoli G., Borri C. Complex terrain effects on wake characteristics of a parked wind turbine, Engineering Structures 110, (2016), pp. 363-374. https://doi.org/10.1016/j.engstruct.2015.11.033.

[48] Lepri P, Večenaj Ž, Kozmar H, Grisogono B Near-ground turbulence of the Bora wind in summertime, Journal of Wind Engineering and Industrial Aerodynamics 147, 2015, pp. 345-357. https://doi.org/10.1016/j.jweia.2015.09.013.

[49] Lepri P., Kozmar H., Večenaj Ž., Grisogono B. A summertime near-ground velocity profile of the Bora wind, Wind and Structures 19(5), (2014), pp. 505-522. https://doi.org/10.12989/was.2014.19.5.505.

[50] Babić N., Večenaj Ž., Kozmar H., de Wekker S., Horvath K., Grisogono B. On turbulent fluxes during strong winter bora wind events, Boundary-Layer Meteorology 158(2), (2016), pp. 331-350. https://doi.org/10.1007/s10546-015-0088-7.

[51] Bajo A., Primorac M., Hanich M. Restructuring and privatization of Croatian shipyards. FISCUS, (2), 2016. (In Croatian)

[52] Hadžić N., Tomić M., Vladimir N., Ostojić S., Senjanović I. Current state and perspectives of the Croatian shipbuilding industry. Journal of Naval Architecture and Marine Engineering, (2015), pp. 3342.

[53] Senjanović I., Hadžić N. Croatian ship production potentials. In: Družić G, Družić I, editors. Development potentials of the Croatian economy. Croatian Academy of Science and Arts, Zagreb 2014. ISBN 978-953-154-279-1 (In Croatian)

[54] Benčić A. Uljanik shipyard energy deputy, personal communication.

[55] Meteorological and Hydrological Service, http://meteo.hr/index_en.php (Accessed on January, 16 2017).

[56] https://www.currentresults.com/Weather/Croatia/sunshine-annual-average.php (Accessed on November 27 2016).

[57] http://www.hep.hr/en, (Accessed on January 10 2017)

[58] http://www.fzoeu.hr/en/home/, (Accessed on January 10 2017)

[59] Eurostat. Greenhouse gas emissions by industries and households. Eurostat, 2016.

[60] National Energy Technology Laboratory. Life Cycle Greenhouse Gas Emissions. Washington, 2015.

Submitted: 05.07.2017. Hadžić Neven, neven.hadzic@fsb.hr

Kozmar Hrvoje

Accepted: $11.12 .2017 . \quad$ Tomić Marko

Faculty of Mechanical Engineering and Naval Architecture,

University of Zagreb, I. Lučića 5, 10000 Zagreb 